\title{
Understanding Meaning and Characteristics of Civic Development in Higher Education
}

\author{
Seyedali Ahrari ${ }^{1}$, Jamilah Bt. Othman ${ }^{1}$, Md. Salleh Hassan ${ }^{1}$, Bahaman Abu Samah ${ }^{1} \&$ Jeffrey D'Silva ${ }^{1}$ \\ ${ }^{1}$ Institute for Social Science Studies, Universiti Putra Malaysia, Malaysia \\ Correspondence: Seyedali Ahrari, Institute for Social Science Studies, Universiti Putra Malaysia, Malaysia. Tel: \\ 60-3-8947-1852. E-mail: seyedaliahrari@gmail.com
}

Received: May 1, 2014 Accepted: May 29, 2014 Online Published: July 24, 2014

doi:10.5539/ass.v10n16p50

URL: http://dx.doi.org/10.5539/ass.v10n16p50

\begin{abstract}
Higher education is a central part of youth life, and its job is to prepare young people to engage in civil society. It is also important in constructing competencies and helping young people to develop a civic identity. Thus, the aim of this study is to explore the meaning and characteristics of civic development among students in the higher education system. A qualitative study using a semi-structural interview is conducted to collect data from 12 international postgraduates of Universiti Putra Malaysia, and the data establishes that three distinct but connected themes-that is, civic knowledge, tendency, and engagement-are key aspects of civic development. The findings relating to these three themes underline the requirements for a civically engaged youth. The findings suggest that policy makers should redesign civic programs based on suitable methods by which to educate students in formal and informal manners.
\end{abstract}

Keywords: higher education, citizenship, civic responsibility, engagement, participation

\section{Introduction}

Civic development meaning in higher education is not clear but it is expected to be goal of any higher education institutions. In an educational sense, civic development refers to learning individual competences, knowledge, and beliefs as a result of educational practice. Students' concepts of civic development expand from a focus on obedience and support of the status quo, to a more critical appraisal, which incorporates the fact that citizens would be irresponsible if they blindly obeyed. However, the ability to become a developed citizen is dependent on knowing one's rights and responsibilities. This knowledge represents another relevant component of civic development (Galston, 2004; Zaff et al., 2011). To date, a number of studies have investigated civic capacities and motivations to develop civically (e.g., Hurtado, Engberg, \& Ponjuan, 2003; Westheimer \& Kahne, 2004). As reported by Annette (2005), there is a lack of understanding about the values of civic development, and the concept of a "civically developed person" has not been well defined with reference to the higher education system. The purpose of the present study is thus to discover the meaning and features of civic development. Thus, this study tries to answer these two questions: How do students see civic development? What are the main components of civic development among higher education students?

\section{Civic Development}

Fudge (2014) describes citizenship as rings of circles that expand outwards. In its simplest form, citizenship refers to members of the public who are honest, unselfish, and behave responsibly towards others (Ho, 2007). In addition, being a good citizen requires social and civic competence. Social competence entails an understanding of how people can ensure social well-being, and it is equally important to understand social practices and recognize cultural issues related to society. The main skill within to this competence is to communicate constructively in different environments, with the aim of collaboration. Civic competence, on the other hand, is based on the concepts of democracy, justice, and civil rights. It includes knowledge of current issues, values, and policies (Essomba, Karatzia-Stavlioti, Maitles, \& Zalieskiene, 2008).

Matten and Crane (2005) identifies three definitions of citizenship: first, a legal definition that emphasizes rights; second, a philosophical definition that determines the relationship of an individual with the state (Deuchar, 2007; Maitles, 2005); and finally, a socio-political definition that stresses the set of practices undertaken by an individual in relation to society (Essomba et al., 2008). Heater (2004) defines a good citizen as an individual that 
is equipped with knowledge of public affairs, instilled with attitudes of civic virtue, and furnished with skills by which to participate in the political arena (p. 343). Such good citizenship can protect young people from risky behaviors, and is connected to good attendance, higher grades, self-esteem, motivation to learn, and political involvement (Eccles, Barber, Stone, \& Hunt, 2003; Perez, Espinoza, Ramos, Coronado, \& Cortes, 2010). In recent years, youth have been marginalized from participation in public fields, especially due to rising poverty, inequality, and isolation, and decreasing support from communities (O'Donoghue \& Kirshner, 2003). In response to these problems, youth are becoming more interested in the civic domain from a scholarly point of view (Putnam, 2007) and want to serve as agents of change (Sherrod, 2007). The first reason for the increased interest of youth in these issues is related to their higher citizenship activity rates compared to those of adults, as well as their engagement in current issues, and collaborative work with peers. The second reason relates to their sense of social inclusion, which is positively related to their assuming an increased level of social responsibility for others, compared to adults (as evidenced, for instance, in voting, volunteering, advertise for political campaigns, charity work, etc.) (Flanagan \& Christens, 2011). Developing and nourishing the above traits will increase youth intention to conduct civic activities, and to become more involved in society overall (Bobek, Zaff, Li, \& Lerner, 2009; Šerek, Lacinová, \& Macek, 2012).

\subsection{Civic Development in Higher Education}

The changes in social and economic patterns of society have produced shifting politics among younger citizens, who are less inclined to feel a sense of duty to participate civically in conventional ways, while displaying a greater inclination to embrace issues connected to lifestyle values, ranging from moral concerns to environmental quality. These new lifestyles entail greater personally expressive or self-actualizing affiliations, which can be fluid and changing. Unfortunately, the sense of duty towards civic practices is still embraced by older citizens, who continue to identify with institutions (parties, churches, unions, service organizations, etc.) (Bennet, Wells, \& Rank, 2009). On the other hand, ideas, beliefs, and behavior towards a good citizen like involvement and responsibility are reduced to uncivic values like consumerism (Giroux, 2003).

Education is a tool by which to help students learn about civil society function (Bennion, 2006) and adapt them to newly emerging lifestyles. Education is key to equipping the new generation with the competencies necessary for participation in public life (Harkavy \& Hartley, 2008; Nobbe, 2012), and is important for building critical thinking skills (Goldfarb, 2002; Reamey, 2011). Higher education plays a major part in encouraging forms of participation like voting, voluntarism, civic responsibility, and civic engagement (Note 1) (Campbell, 2006; Misa, Anderson, \& Yamamura, 2005). Furthermore, length of formal education has a high correlation with civic knowledge (Dudley \& Gitelson, 2003), and plays a vital role in a complex postmodern society (Elias, 2005), especially when democracy is viewed as a form of government and as a practice (Essomba et al., 2008).

Many studies justify the connection between higher education and civic participation (e.g., Brand, 2010; Dee, 2004; Gesthuizen, Van der Meer, \& Scheepers, 2008; Huang, Maassen van den Brink, \& Groot, 2009). The way in which citizenship education is designed determines the kind of citizens youth become (Westheimer \& Kahne, 2004). Such education aims to equip youth with knowledge, skills, and values for participation in society, and encourages youth to reconstruct their society and prevent problems like racism, addiction, and inequality. In order to be effective citizens, youth need to have their own understanding of their role in society, and acquire an ability to validate logic of the knowledge they obtain (Lee, 2000).

Aim of each educational program is to develop civic characteristics among students (Colby, Ehrlich, Beaumont, \& Stephens, 2003). Some researchers seek to identify issues determining these characteristics by calling education as a key role in bringing youth to action (Brand, 2010) via socialization (Dee, 2004; Gesthuizen, Van der Meer, \& Scheepers, 2009). It seems that universities are far from their task (Giroux, 2009; Huang et al., 2009), but on the other hand actively encourage students to participate in certain formal actions that support long-term civic commitments (Checkoway, Allison, \& Montoya, 2005; Johnson, 2004) and facilitate civic involvement, which causes a cognitive outcome in relation to participation (Metzger \& Ferris, 2013). These highly educated and developed youth are more likely to be invited to participate in civic activities (Gesthuizen et al., 2008; Musick \& Wilson, 2008). Research also shows that study in universities is related to higher income, which is linked to a higher level of civic participation (Brand, 2010; Gibson, 2001). Even with such conclusive evidence of the benefits of higher education to civic development, university programs typically provide inadequate descriptions of, and pay inattention to, the concept of citizenship (Gimpel, Lay, \& Schuknecht, 2003; O'Donoghue \& Kirshner, 2003). The problems faced by higher education in this regard can be seen as consisting of five parts. First, universities lack financial resources, have a traditional view of teaching (e.g., follow a totalitarian approach), focus on very formal and unrelated practices of student participation, and are assessment-orientated (Essomba et al., 2008). Second, higher education faces a challenge of managing time for 
civic subjects in classrooms (Smith, Ottewill, Jubb, Sperling, \& Wyman, 2008). Third, education policy makers lack the expertise to design programs that are truly suited to civic-related practices. Fourth, civic education tends to focus more on textbooks than on teaching students about real engagement practices (Bennet et al., 2009). Finally, there is a lack of the teaching civic subjects' feedback from students (Biesta, 2009).

\subsubsection{Students' Civic Identity Development}

Civic identity involves a sense of membership to a community (Owen, 2004), and is viewed as a vital part of each citizen's self (Beaumont, Colby, Ehrlich, \& Torney-Purta, 2006; Pratt, Hunsberger, Pancer, \& Alisat, 2003). It is a useful construct in predicting young people's future beliefs, ideas, aims and civic development in general. Previous research has noted the relationship between identity and youth civic development (Colby, Beaumont, Ehrlich, \& Corngold, 2007; Colby, Ehrlich, Beaumont, \& Stephens, 2003; Crocetti, Jahromi, \& Meeus, 2012; Flanagan, Martinez, \& Cumsille, 2010; Hardy, Pratt, Pancer, Olsen, \& Lawford, 2010; Porter, 2013). Pancer, Pratt, Hunsberger, and Alisat (2007) identified a relationship between development of civic identity, and civic involvement. They found that participation in civic activities aids development of civic identity during the transition to adulthood. Thus, youth with advanced civic identities show more responsibility for their societies, political activities, and pro-social behaviors (e.g., community service, altruism, etc.) (Crocetti et al., 2012; Hardy \& Kisling, 2006).

\subsection{Existing Literature on Youth Civic Development}

There are extensive studies about student civic development in the higher-education literature. Civic development is defined as the way in which students cultivate competencies through their enrolment and involvement in education programs (Amnå, 2012). There are three main civic development approaches. The first is based on personal development. It refers to the problem of declining civic engagement and the lack of skills, values, and motivation therein, and tries to solve this obstacle by proposing to educate students on civic action. It suggests that citizenship education is a key agent for change (Colby et al., 2007; McDevitt \& Kiousis, 2004; Morrison, Rha, \& Helfman, 2010; Tuomi, Jacott, \& Lundgren, 2008). The second perspective is rooted in democratic theories. It emphasizes the problem of an unstable democracy in terms of an absence of places in society in which individuals can engage civically. The suggested solution to this is engaging students in the process of shared learning in certain places (e.g., classroom, campus, etc.) (e.g., Annette, 2010). The final perspective on civic development is based on social change theories. Here, a problem is identified in terms of the need to solve serious social issues. To this end, related institutions (e.g., universities, colleges) must improve their teaching programs towards leaner-centered programs (e.g., Ostrander, 2004).

There are also two main theories about students' civic development. First, socialization theory sees education as influencing communities by socializing people. This theory was introduced in relation to high-school-aged students (Flanagan \& Christens, 2011); in contrast to universities, schools provide few opportunities for students in terms of civic engagement (O’Donoghue \& Kirshner, 2003). Gimpel, Lay, and Schuknecht (2003) provided a new concept of political socialization, as the process by which students are inducted into political culture, knowledge, values, and attitudes that contribute to supporting the political system. The second theory about civic development in higher education is mobilization theory. This emphasizes that educated youth have will have a stronger desire to participate with respect to civic activities, compared to those with lower education levels (Bennion, 2006; Brand, 2010).

\subsubsection{Civic Development Stages}

According to sociopolitical development theory, students' civic development occurs in five steps: gaining knowledge, logical skills, emotional abilities, political capabilities, and social competences (Watts, Williams, \& Jagers, 2003). "Gaining knowledge" is a cognitive stage, which can be translated as social and emotional development (Miller, 2002). Yusuf (2005) perceived citizenship education as a vital tool by which to transform value orientation at this stage. It is a crucial stage for revealing unfamiliarity with social problems. During the "logical skills" stage, social problems (e.g., inequality, prejudice) are recognized without the youth having any ability to contribute to change. In the "emotional abilities" stage young people start to civically address these problems. In the "political capabilities" stage, youth have a desire to learn and participate about civic issues. Finally, in the "social competences" stage, youth start to engage in activities for addressing social problems (Watkins, 2009). In this final stage, youth start to recognize their relationship with the civil society which means civic identity development (Knefelkamp, 2008).

\section{Data Collection Methods}

While previous studies have used quantitative techniques, such approaches are not suitable for intention of this 
study (because of limitations of software programs to interpret true meaning of a sociological construct in youth mind), which is to conceptualize the meaning of civic development. Thus, the constructivism research paradigm was used in this study because of its ability to produce reconstructed understandings of social phenomena (Denzin \& Lincoln, 2005, p. 184) through personal experiences outlined by interviewees, since interviewees' interpretations are not constructed in isolation (Schwandt, 2007). Hence, using this paradigm creates meaning through interpretation of participants' understanding (Boren, 2011). According to Zaremohzzabieh, Bahaman, Omar, Bolong, and Kamarudin (2014) addressing participant's thoughts needs detailed examination of his or her undergoes because of complexity of human mind. According to Kozinets (2002), qualitative methods are most reliable for revealing the deep detail. Therefore, the research is most suited for a qualitative method because the approach offers more chance to get into the respondents' thoughts.

Polit and Beck (2006) described interviews as a technique for gathering data in which one individual asks questions of another; it is one of the most popular technique for collecting data (DiCicco-Bioom \& Crahtree, 2006). The researcher thereby uncovers limited overall issues to help discover the participants' opinions; they explore a few general issues to help uncover the participants' viewpoints, but otherwise respect how the participants frame their responses (Marshall \& Rossman, 2010). Qualitative interviews include a variety of methods, with many studies loosely distinguishing qualitative interviews as unstructured, semi-structured and structured (Fontana \& Frey, 2005; Johnson, 2002). We selected semi-structured interviews for our study, which were conducted with 12 international postgraduate students. According to Guest, Bunce, and Johnson (2006) 12 interviews should be sufficient for an interviewer to distinguish different themes about shared experiences among similar respondents.

An interview protocol was provided to notify the interviewees of their right to terminate the interview session at any time, or skip over sensitive questions; it also explained that each interview must not exceed one hour (Yin, 2009). The qualitative researchers need to attend to the particular location under study. Thus, Universiti Putra Malaysia (UPM) was selected as the data-collection location. UPM is a public university that is among the top five in Malaysia, and is an attractive place for diverse students from different backgrounds. The criterion for choosing the target sample was based on their cultural representativity as international students in higher education, and not on demographic factors. Random sampling was employed to select the participant group to prevent bias (Shenton, 2004); this is based on the notion that the researcher selects a sample from which the most can be learned (Merriam, 2009).

The interviewees were chosen from all fields of study, including human sciences, engineering, and agriculture. The interviews took place in the lobby of the university library. Before starting, a semi-structured interview checklist containing five parts designed to inform the interviewee about the reason for the study, record interviewees' answers, develop report from their answers, ask guided questions for detailed and decide the end of interview session. The questions used in this research were purposefully designed based on the literature review, in order to address the students' beliefs and experience about civic development. Although each of the semi-structured interviews began with specific opening questions, new questions arose during the session, as is often the case with qualitative methodology. The iterative questioning method (Shenton, 2004) was used to prevent any false replies from being given. Employing a semi-structured procedure made it possible to follow up on unpredicted themes or individual changes that arose from the set of answers to the main questions asked.

\section{Data Analysis}

There is no fully recognized distinction between the data-collection and-analysis stages of research (Gorgol, 2012) when using semi-structured interviews. Based on the significance of comprehending the situation and setting (Ginwright, 2005), focused attention was given to the characteristics of civic development and the university context. During the interview process, dialogues were conducted on the civic experience the interviewees faced within the university. After completing the interviews, the findings were analyzed, and three themes were identified. Each of these is reviewed in detail in below.

\section{Results}

Three main themes were identified regarding civic development from the interviewees' responses (Table 1). 
Table 1. Summary of key themes

\begin{tabular}{ll}
\hline Theme & Evidence from Interviewees \\
\hline \multirow{3}{*}{ Civic Knowledge } & Learning common values \& norms \\
& Formal and informal learning activities \\
& Learning through interaction \\
& Responsibility towards community \\
Civic Tendency & Caring about current issues \\
& Desire to help community \\
& Engagement in current issues \\
Civic Engagement & Volunteering \\
& Collective action \\
\hline
\end{tabular}

\subsection{Theme One: Knowledge about Civic Information and Rules}

Many participants highlighted the aspect of values and norms of society. Both male and female interviewees agreed that universities are ideal places in which to learn values and norms. However, interestingly, the male participants noted the importance of informal learning activities, stating that they prefer to learn norms via interaction with their peers and discuss community issues with faculty members, especially their lecturers. In contrast, the female participants prefer to learn about these values from inside of classrooms, especially when classes are more diverse (consisting of different races, opinions, minorities, etc.). Both groups considered studying social subjects, attending seminar classes, and having group discussions as their main sources of information. In addition, they mentioned new ways of learning about civic and political issues in terms of using social networking sites. One of the male students stated: "Because I am now far from my country, I use the Internet and this helps me to be aware about recent political issues faster than my family and friends."

\subsection{Theme Two: Tendency towards Civic Value}

The interviewees made many statements related to their opinions about citizenship characteristics, and about their understanding of these. All of the interviewees also stated that the most important aspect of being a good citizen is to help society and address its issues. For instance, one female participant stated: "I usually care about everything happen in my society and my surrounding[s]." However, all of the female participants noted that they wish to address the increasing problems of society, such as prejudice and injustice. Interestingly, one of the female students complained about corruption (e.g., bribery) among the government, and suggested that a real good citizen is a person that follows the rules of their country. When asked how universities could help to solve this problem, she stated: "University is a late stage for socialization but through interaction with similar nationals and friends, you gain a sense of patriotism and responsibility to act and change the situation cooperatively."

\subsection{Theme Three: Engagement in Citizenship Activities}

Some of participants stated that the most important issue in citizenship is engagement in social and political activities. As noted above, civic identity development will occur through engagement in such activities. The interviewees pointed to their membership in non-governmental organizations, volunteering in public activities, and charity work. The participants also highlighted participation in community service. The most frequent point highlighted by both the male and female students was charity work as a symbol of civic engagement. One of the male participants said: "I will help [for] poor people by donating money as a main practice in my religion and this can change their lives and makes them happy." The majority of female participants proclaimed a belief in collective, rather than individual, action. One female student stated: "I will serve myself for my community and I consider all of my community problems as my problem." By way of example, she said: "During the last week, I attended [a] tree planting campaign held by my university. I think it is my duty to the community and next generation." In addition, filling out online petitions was highlighted by one of the male participants: "I signed an online petition with other neighbors for [the] municipal office to solve problem[s] of rubbish near my [home]." Interestingly, all students noted that civic engagement involves a process of learning, and is a kind of practice for their future role in society.

\section{Discussion and Conclusion}

The aim of this study was to conceptualize the meaning of youth civic development. Three main themes have been discovered. The first and the most important component of civic development is gaining civic knowledge as 
first stage of civic development (Dudley \& Gitelson, 2003), which is needed for students' civic engagement (Watkins, 2010). The second theme is civic tendency, which entails students personalizing civic knowledge, and involves a contextualization of learning, as well as critical thinking. Finally, employing this knowledge and these tendencies will lead to engagement in civic activities (Jennings, Parra-Medina, Hilfinger-Messias, \& McLoughlin, 2006; Watts \& Flanagan, 2007). The outcomes reveal the thoughts associated with the civic development process. The study indicates common civic outcomes in relationship with educational programs (e.g., social studies classes, co-curricular activities, etc.). The findings also indicate that through youth participation in programs, they acquire a number of general skills and knowledge. This study confirms three main citizenship outcome in other studies (Eccles et al., 2003; McLaughlin \& Talbert, 2006) like civic knowledge, disposition, and engagement associated with educational programs. Prior research has shown that higher education transforms communities by providing students with information and competences from which they can play significant roles within their societies (e.g., Bardaglio \& Putman, 2009; Boren, 2011; Colby et al., 2003). In addition, education and civic outcomes are closely intertwined (Ferreira, Azevedo, \& Menezes, 2012; Munene, 2006). Finally, this study highlights new ways for civic learning and engagement civic, such as using the Internet. This study enhances this idea proposed by Youniss, Bales, Christmas-Best, Diversi, McLaughlin, and Silbereisen (2002) and Boyd, Zaff, Phelps, Weiner, and Lerner (2011), which underline the role of social media in shaping and reinforcing social competences among youth.

\section{Implications}

The paper extends past studies on youth civic development by suggesting the follow implications:

\subsection{Implication for Policy}

1) The findings of this study suggest that higher education institutions should consider information and communication technologies as providing new ways for their students to engage in social and civic activities.

2) In particular, the study reveals the ways in which student develop civic awareness through formal and informal activities, and it is recommended that universities pay more attention to campus-wide learning about civic outcomes.

3) In order to foster youth civic development, policy makers must increase their focus on promoting more learner-centered approaches by involving students in discussions, decisions, and problem solving, both in and outside of classes.

\subsection{Implications for Practice}

1) Higher-education intuitions need to redesign their programs which are suitable for youth.

2) Reflecting on the meaning of civic development provided here, students should be able to apply different strategies for civic learning throughout the education period.

\subsection{Implications for Research}

Since youth civic development is based on their learning and experience, more research is needed to investigate the interrelation between university learning and community-based learning.

\section{References}

Amnå, E. (2012). How is civic engagement developed over time? Emerging answers from a multidisciplinary field. Journal of Adolescence, 35, 611-627. http://dx.doi.org/10.1016/j.adolescence.2012.04.011

Annette, J. (2005). Character, Civic Renewal and Service Learning for Democratic Citizenship in Higher Education. British Journal of Educational Studies, 53(3), 326-340. http://dx.doi.org/10.1111/j.1467-8527. 2005.00298.x

Annette, J. (2010). The Challenge of Developing Civic Engagement in Higher Education in England. British Journal of Educational Studies, 58(4), 451-463. http://dx.doi.org/10.1080/00071005.2010.527669

Bardaglio, P. W., \& Putman, A. (2009). Boldly sustainable: Hope and opportunity for higher education in the age of climate change. Washington DC: NACUBO.

Beaumont, E., Colby, A., Ehrlich, T., \& Torney-Purta, J. (2006). Promoting political competence and engagement in college students. Journal of Political Science Education, 2, 249-270. http://dx.doi.org/10. $1080 / 15512160600840467$

Bennet, W. C., Wells, C., \& Rank, A. (2009). Young citizens and civic learning: Two paradigms of citizenship in the digital age. Citizenship Studies, 13(2), 105-120. http://dx.doi.org/10.1080/13621020902731116 
Bennion, E. A. (2006). Civic Education and Citizen Engagement: Mobilizing Voters as a Required Field Experiment. Journal of Political Science Education, 2(2), 205-227. http://dx.doi.org/10.1080/155121606 00686555

Biesta, G. (2009). What Kind of Citizenship for European Higher Education? Beyond the Competent Active Citizen. European Educational Research Journal, 8(2). http://dx.doi.org/10.2304/eerj.2009.8.2.146

Bobek, D., Zaff, J., Li, Y., \& Lerner, R. M. (2009). Cognitive, emotional, and behavioral components of civic action: Towards an integrated measure of civic engagement. Journal of Applied Developmental Psychology, 30(5), 615-627. http://dx.doi.org/10.1016/j.appdev.2009.07.005

Boren, L. D. (2011). Campus Environmental Factors Influencing Student Leadership Development and Civic Engagement (PhD dissertation). Texas A\&M University, Texas.

Boyd, M. J., Zaff, J. F., Phelps, E., Weiner, M. B., \& Lerner, R. M. (2011). The relationship between adolescents' news media use and civic engagement: The indirect effect of interpersonal communication with parents. Journal of Adolescence, 34(6), 1167-1179. http://dx.doi.org/10.1016/j.adolescence.2011.07.004

Brand, J. E. (2010). Civic Returns to Higher Education: A Note on Heterogeneous Effects. Social Forces, 89(2), 417-433. http://dx.doi.org/10.1353/sof.2010.0095

Campbell, D. T. (2006). Education's Impact on Civic and Social Engagement. In T. Desjardins, \& T. Schuller (Eds.), Measuring the Effects of Education on Health and Civic/Social Engagement (pp. 25-126). Paris: OECD.

Checkoway, B., Allison, T., \& Montoya, C. (2005). Youth participation in public policy at the municipal level. Children and Youth Services Review, 27(10), 1149-1162. http://dx.doi.org/10.1016/j.childyouth.2005.01.001

Colby, A., Beaumont, E., Ehrlich, T., \& Corngold, J. (2007). Educating for democracy: Preparing undergraduates for responsible political engagement. San Francisco, CA: Jossey-Bass Publishers.

Colby, A., Ehrlich, T., Beaumont, E., \& Stephens, J. (2003). Educating citizens: Preparing America's undergraduates for lives of moral and civic responsibility. San Francisco, CA: Jossey-Bass.

Crocetti, E., Jahromi, P., \& Meeus, W. (2012). Identity and civic engagement in adolescence. Journal of Adolescence, 35, 521-532. http://dx.doi.org/10.1016/j.adolescence.2011.08.003

Dee, T. S. (2004). Are there civic returns to education? Journal of Public Economics, 88, 1697-1720. http://dx.doi.org/10.1016/j.jpubeco.2003.11.002

Denzin, N. K., \& Lincoln, Y. S. (2005). Introduction: The discipline and practice of qualitative research. In N. K. Denzin, \& Y. S. Lincoln (Eds.), Handbook of qualitative research (3rd ed.). Thousand Oaks, CA: SAGE publications.

Deuchar, R. J. (2007). Citizenship, enterprise and learning: Harmonizing competing educational agendas. Trentham Books. Retrieved from http://strathprints.strath.ac.uk/8498/

DiCicco-Bioom, B., \& Crahtree, B. F. (2006). The qualitative research interview. Medical Education, 40(4), 314-321. http://dx.doi.org/10.1111/j.1365-2929.2006.02418.x

Dudley, R. L., \& Gitelson, A. R. (2003). Civic education, civic engagement, and youth civic development. Political Science and Politics, 36(2), 263-267. http://dx.doi.org/10.1017/S1049096503002191

Eccles, J. S., Barber, B. L., Stone, M., \& Hunt, J. (2003). Extracurricular activities and adolescent development. Journal of Social Issues, 59(4), 865-889. http://dx.doi.org/10.1046/j.0022-4537.2003.00095.x

Elias, J. L. (2005). Philosophical foundations of adult education. Retrieved from http://philpapers.org/rec/ ELIPFO

Essomba, M. A., Karatzia-Stavlioti, E., Maitles, H., \& Zalieskiene, I. (2008). Developing the conditions for Education for Citizenship in Higher Education (No. 26236). CiCe Thematic Network Project. Retrieved from http://www.londonmet.ac.uk/fms/MRSite/Research/cice/pubs/hec/hec-design-07.pdf

Ferreira, P. D., Azevedo, C. N., \& Menezes, I. (2012). The developmental quality of participation experiences: Beyond the rhetoric that "participation is always good!" Journal of Adolescence, 35(3), 599-610. http://dx. doi.org/10.1016/j.adolescence.2011.09.004

Flanagan, C. A., \& Christens, B. D. (2011). Youth civic development: Historical context and emerging issues. In C. A. Flanagan, \& B. D. Christens (Eds.), Youth civic development: Work at the cutting edge (Vol. 134, pp. 1-9). New Directions for Child and Adolescent Development. 
Flanagan, C. A., Martinez, M. L., \& Cumsille, P. (2010). Civil societies as cultural and developmental contexts for civic identity formation. In L. A. Jensen (Ed.), Bridging cultural and developmental approaches to psychology. Oxford: Oxford University Press. http://dx.doi.org/10.1093/acprof:oso/9780195383430.003. 0006

Fontana, A., \& Frey, J. (2005). The interview: From neutral stance to political involvement. In N. Denzin, \& Y. Lincoln (Eds.), The Sage Handbook of Qualitative Research (3rd ed., pp. 695-727). Thousand Oaks, CA: SAGE publications.

Fudge, J. (2014). Making claims for migrant workers: Human rights and citizenship. Citizenship Studies, 18(1), 29-45. http://dx.doi.org/10.1080/13621025.2014.865894

Galston, W. A. (2004). Civic Education and Political Participation. Political Science and Politics, 37(2), 263-266. http://dx.doi.org/10.1017/S1049096504004202

Gesthuizen, M., Van der Meer, T., \& Scheepers, P. (2008). Education and Dimensions of Social Capital: Do educational effects differ due to educational expansion and social security expenditure? European Sociological Review, 24(5), 617-632. http://dx.doi.org/10.1093/esr/jcn021

Gesthuizen, M., Van der Meer, T., \& Scheepers, P. (2009). Ethnic diversity and social capital in Europe: Tests of Putnam's thesis in European countries. Scandinavian Political Studies, 32(2), 121-142. http://dx.doi.org/10. 1111/j.1467-9477.2008.00217.x

Gibson, R. (2001). Elections online: Assessing Internet voting in light of the Arizona Democratic primary. Political Science Quarterly, 116(4), 561-583. http://dx.doi.org/10.2307/798221

Gimpel, J. G., Lay, C. J., \& Schuknecht, J. E. (2003). Cultivating Democracy. Washington DC: Brookings Institution Press.

Ginwright, S. (2005). Toward a politics of relevance: Race, resistance and African American youth activism. In Youth Activism: A Web Forum Organized by the Social Science Research Council. Retrieved from http://ya.ssrc.org/african/Ginwright

Giroux, H. A. (2003). Youth, Higher Education, and the Crisis of Public Time: Educated Hope and the Possibility of a Democratic Future. Journal for the Study of Race, Nation and Culture, 9(2), 141-168.

Giroux, H. A. (2009). Youth in a suspect society. New York, NY: Palgrave Macmillan. http://dx.doi.org/10.1057 19780230100565

Goldfarb, J. C. (2002). Anti-Ideology: Education and Politics as Democratic Practices. In R. Castronovo, \& D. Nelson (Eds.), Materializing Democracy. Durham: Duke University Press. http://dx.doi.org/10.1215/97808 22383901-014

Gorgol, L. E. (2012). Understanding The Influence Of The College Experience On The Civic Development Of Undergraduate Students (PhD dissertation). University of Pennsylvania.

Guest, G., Bunce, A., \& Johnson, L. (2006). How many interviews are enough? An experiment with data saturation and variability. Field Methods, 18(1), 59-82. http://dx.doi.org/10.1177/1525822X05279903

Hardy, S. A., \& Kisling, J. W. (2006). Identity statuses and prosocial behaviors in young adulthood: A brief report. Identity: An International Journal of Theory and Research, 6, 363-369. http://dx.doi.org/10.1207/ s1532706xid0604_4

Hardy, S. A., Pratt, M. W., Pancer, S. M., Olsen, J. A., \& Lawford, H. L. (2010). Community and religious involvement as contexts of identity change across late adolescence and emerging adulthood. International Journal of Behavioral Development, 35, 125-135. http://dx.doi.org/10.1177/0165025410375920

Harkavy, I., \& Hartley, M. (2008). Pursuing Franklins' democratic vision for higher education. Peer Review, Association of American Colleges and Universities, 13-17.

Heater, D. (2004). Citizenship: The civic ideal in world history, politics and education. Manchester, UK: Manchester University Press.

Ho, P. (2007). Embedded activism and political change in a semi-authoritarian context. China Information, 21(2), 187-209. http://dx.doi.org/10.1177/0920203X07079643

Huang, J., Maassen van den Brink, H., \& Groot, W. (2009). A meta-analysis of the effect of education on social capital. Economics of Education Review, 28(4), 454-464. http://dx.doi.org/10.1016/j.econedurev.2008. 03.004 
Hurtado, S., Engberg, M. E., \& Ponjuan, L. (2003). The impact of the college experience on students'learning for a diverse democracy. In annual meeting of the Association for the Study of Higher Education, Portland, OR. Retrieved from http://www.umich.edu/ divdemo/Ashe03num2.pdf

Jennings, L. B., Parra-Medina, D. M., Hilfinger-Messias, D. K., \& McLoughlin, K. (2006). Toward a critical social theory of youth empowerment. Journal of Community Practice, 14(1-2), 31-55. http://dx.doi.org/10. 1300/J125v14n01_03

Johnson, D. I. (2004). Relationships between college experiences and alumni participation in the community. The Review of Higher Education, 27(2), 169-185. http://dx.doi.org/10.1353/rhe.2003.0061

Johnson, J. (2002). In-depth interviewing. In J. Gubrium, \& J. Holstein (Eds.), Handbook of Qualitative Research (pp. 103-119). Thousand Oaks, CA: Sage Publications.

Knefelkamp, L. L. (2008). Civic identity: Locating self in community. Diversity and Democracy, 11(2), 1-3.

Kozinets, R. V. (2002). The field behind the screen: Using netnography for marketing research in online communities. Journal of Marketing Research, 39(1), 61-72. http://dx.doi.org/10.1509/jmkr.39.1.61.18935

Lee, D. (2000). Transformative Citizenship: A Redefinition of Citizenship in a Multicultural Society. The SNU Journal of Education Research.

Maitles, H. (2005). Values in education: We're all citizens now. Dunedin Academic Press. Retrieved from http://strathprints.strath.ac.uk/3193/

Marshall, C., \& Rossman, G. B. (2010). Designing qualitative research. London, UK: Sage.

Matten, D., \& Crane, A. (2005). Corporate citizenship: Toward an extended theoretical conceptualization. Academy of Management Review, 30(1), 166-179. http://dx.doi.org/10.5465/AMR.2005.15281448

McDevitt, M., \& Kiousis, S. (2004). Education for deliberative democracy: The long-term influence of Kids Voting (Working Paper No. 22).

McLaughlin, M. W., \& Talbert, J. E. (2006). Building school-based teacher learning communities: Professional strategies to improve student achievement (Vol. 45). Teachers College Press. Retrieved from $\mathrm{http} / /$ books.google.com.my/books?hl=en\&lr=\&id=Cbun3D3ZsmUC\&oi=fnd\&pg=PR7\&dq=\%22MW+Mc Laughlin\%22\&ots=LBA11c9bvV\&sig=jzzPhmNlZCfRHP_Fz2wKKuXmIr0

Meikle-Yaw, P. A. (2006). Democracy Satisfaction: The Role of Social Capital and Civic Engagement in Local Communities ( $\mathrm{PhD}$ dissertation). Mississippi State University.

Merriam, S. B. (2009). Qualitative Research: A Guide to Design and Implication (2nd ed.). San Francisco, CA: Jossey-Bass.

Metzger, A., \& Ferris, K. (2013). Adolescents' domain-specific judgments about different forms of civic involvement: Variations by age and gender. Journal of Adolescence, 36(3), 529-538. http://dx.doi.org/10. 1016/j.adolescence.2013.03.003

Miller, P. H. (2002). Theories of developmental psychology (4th ed.). New York, NY: Worth Publishers.

Misa, K., Anderson, J., \& Yamamura, E. (2005). The lasting impact of college on young adults' civic and political engagement. In Association for the Study of Higher Education Annual Conference (pp. 1-38). Philadelphia, PA. Retrieved from https://heri.ucla.edu/PDFs/Lasting\%20Impact\%20of\%20College\%20-\% 20ASHE05.pdf

Morrison, J. L., Rha, J., \& Helfman, A. (2010). Learning Awareness, Student Engagement, and Change: A Transformation in Leadership Development. Journal of Education for Business, 79(1), 11-17. http://dx.doi. org/10.1080/08832320309599081

Munene, M. (2006). Conflict and Conflict Management in Kenya from 1963 to 2005. In J. Kamenju, \& O. P. Godfrey (Eds.), Power and Power Politics in Kenya: An Interdisciplinary Discourse. Nairobi: SRIC.

Musick, M. A., \& Wilson, J. (2008). Volunteering: A social profile. Bloomington, IN: Indiana University Press.

Nobbe, J. E. (2012). Citizenship Education in Public Higher Education: Curricular Strategies to Promote the Development of Civic Knowledge, Skills, and Attitudes (PhD dissertation). University of Minnesota.

O'Donoghue, J. L., \& Kirshner, B. R. (2003). Urban youth's civic development in community-based youth organizations. In International Conference on Civic Education. New Orleans, LA. Retrieved from http://jgc.stanford.edu/resources/conferences/JOD-BK_Urban\%20Youth\%20Civic\%20Outcomes_1103.pdf 
Ostrander, S. A. (2004). Democracy, civic participation, and the university: A comparative study of civic engagement on five campuses. Nonprofit and Voluntary Sector Quarterly, 33(1), 74-93. http://dx.doi.org/10. $1177 / 0899764003260588$

Owen, D. (2004). Citizenship Identity and Civic Education in the United States. In Civic Education and Politics in Democracies Conference. San Diego, CA.

Pancer, M. S., Pratt, M., Hunsberger, B., \& Alisat, S. (2007). Community and political involvement in adolescence: What distinguishes the activists from the uninvolved? Journal of Community Psychology, 35, 741-759. http://dx.doi.org/10.1002/jcop.20176

Perez, W., Espinoza, R., Ramos, K., Coronado, H., \& Cortes, R. (2010). Civic engagement patterns of undocumented Mexican students. Journal of Hispanic Higher Education, 9(3), 245-265. http://dx.doi.org/ $10.1177 / 1538192710371007$

Polit, D. F., \& Beck, C. T. (2006). Essentials of Nursing Research. Methods, Appraisal, and Utilization (6th ed.). Philadelphia PA.: Lippincott Williams and Wilkins.

Porter, T. J. (2013). Moral and political identity and civic involvement in adolescents. Journal of Moral Education, 42(2), 239-255. http://dx.doi.org/10.1080/03057240.2012.761133

Pratt, M. W., Hunsberger, B., Pancer, S. M., \& Alisat, S. (2003). A longitudinal analysis of personal value socialization: Correlates of moral self-ideal in adolescence. Social Development, 12, 563-585. http://dx.doi. org/10.1111/1467-9507.00249

Putnam, R. D. (2007). E pluribus unum: Diversity and community in the twenty-first century the 2006 Johan Skytte Prize Lecture. Scandinavian Political Studies, 30(2), 137-174. http://dx.doi.org/10.1111/j.1467-9477. 2007.00176.x

Reamey, R. A. A. (2011). Engaged Citizenship: The Effect of Blackburn Institute Participation on Post-Graduate Behaviors and Beliefs (PhD dissertation). The University of Alabama, Tuscaloosa, Alabama.

Schwandt, T. A. (2007). The Sage dictionary of qualitative inquiry. Sage Publications New York. Retrieved from http://www.onlinecef.net/file.php/1/CEF_Resources/Research\%20\%20Method/CRITICAL_ETHNOGRAP HY\%5B1\%5D.pdf

Šerek, J., Lacinová, L., \& Macek, P. (2012). Does family experience influence political beliefs? Relation between interparental conflict perceptions and political efficacy in late adolescence. Journal of Adolescence, 35(3), 577-586. http://dx.doi.org/10.1016/j.adolescence.2011.10.001

Shenton, A. K. (2004). Strategies for ensuring trustworthiness in qualitative research projects. Education for Information, 22, 63-75.

Sherrod, L. (2007). Civic engagement as an expression of positive youth development. London, UK: Sage Publications.

Smith, G., Ottewill, R., Jubb, E., Sperling, E., \& Wyman, M. (2008). Teaching citizenship in higher education. European Political Science, 7(2), 135-143. http://dx.doi.org/10.1057/eps.2008.8

Tuomi, M. T., Jacott, L., \& Lundgren, U. (2008). Education for World Citizenship: Preparing students to be agents of social change. London, England: CiCe Thematic Network Project. Retrieved from http://www.londonmet.ac.uk/fms/MRSite/Research/cice/pubs/citizenship/citizenship-06.pdf

Watkins, N. D. (2009). The Civic Development of Youth of Color in Urban Community-Based Youth Programs: Understanding Process and Context ( $\mathrm{PhD}$ dissertation). University of Illinois at Urbana-Champaign, Urbana, Illinois.

Watkins, N. D. (2010). The civic development of youth of color in urban community-based youth programs: Understanding process and context. University of Illinois at Urbana-Champaign. Retrieved from https://www.ideals.illinois.edu/handle/2142/14584

Watts, R. J., \& Flanagan, C. (2007). Pushing the Envelope on Youth Civic Engagement: A Developmental and Liberation Psychology Perspective. Journal of Community Psychology, 35(6), 779-792. http://dx.doi.org/ 10.1002/jcop. 20178

Watts, R. J., Williams, N. C., \& Jagers, R. J. (2003). Sociopolitical development. American Journal of Community Psychology, 31(1-2), 185-194. http://dx.doi.org/10.1023/A:1023091024140

Westheimer, J., \& Kahne, J. (2004). What Kind of Citizen? The Politics of Educating for Democracy. American 
Educational Research Journal, 41, 239. http://dx.doi.org/10.3102/00028312041002237

Yin, R. K. (2009). Case study research: Design and methods (Vol. 5). Thousand Oaks, CA: Sage Publications.

Youniss, J., Bales, S., Christmas-Best, V., Diversi, M., McLaughlin, M., \& Silbereisen, R. (2002). Youth civic engagement in the twenty-first century. Journal of Research on Adolescence, 12(1), 121-148. http://dx.doi. org/10.1111/1532-7795.00027

Yusuf, A. (2005). Citizenship education: An instrument for unity and stability in Nigeria. Retrieved from http://www.musero.org/citizenship_education.pdf

Zaff, J. F., Kawashima-Ginsberg, K., Lin, E. S., Lamb, M., Balsano, A., \& Lerner, R. M. (2011). Developmental trajectories of civic engagement across adolescence: Disaggregation of an integrated construct. Journal of Adolescence, 34(6), 1207-1220. http://dx.doi.org/10.1016/j.adolescence.2011.07.005

Zaremohzzabieh, Z., Bahaman, A. S., Omar, S. Z., Bolong, J., \& Kamarudin, N. A. (2014). Addictive Facebook Use among University Students. Asian Social Science, 10(6), 107-116. http://dx.doi.org/10.5539/ass. v10n6p107

\section{Note}

Note 1. Actions to solve problems in a society in both civic and political realm stated by Meikle-Yaw (2006).

\section{Copyrights}

Copyright for this article is retained by the author(s), with first publication rights granted to the journal.

This is an open-access article distributed under the terms and conditions of the Creative Commons Attribution license (http://creativecommons.org/licenses/by/3.0/). 